\title{
Use of Oxidative Stress Responses to Determine the Efficacy of Inactivation Treatments on Cryptosporidium Oocysts
}

\author{
Tamirat Tefera Temesgen ${ }^{1,2, *}$, Kristoffer Relling Tysnes ${ }^{1}$ and Lucy Jane Robertson ${ }^{1}$ (D) \\ 1 Laboratory of Parasitology, Department of Paraclinical Sciences, Faculty of Veterinary Medicine, Norwegian \\ University of Life Sciences, Oluf Thesens vei 22, 1433 Ås, Norway; kristoffer.tysnes@nmbu.no (K.R.T.); \\ lucy.robertson@nmbu.no (L.J.R.) \\ 2 NABAS AS, Moer Allé 33, 1435 Ås, Norway \\ * Correspondence: tamirat.temesgen@nabas.no or nagaakoo@gmail.com
}

Citation: Temesgen, T.T.; Tysnes, K.R.; Robertson, L.J. Use of Oxidative Stress Responses to Determine the Efficacy of Inactivation Treatments on Cryptosporidium Oocysts. Microorganisms 2021, 9, 1463.

https://doi.org/10.3390/

microorganisms 9071463

Academic Editor: Eric Viscogliosi

Received: 16 June 2021

Accepted: 5 July 2021

Published: 8 July 2021

Publisher's Note: MDPI stays neutral with regard to jurisdictional claims in published maps and institutional affiliations.

Copyright: (C) 2021 by the authors Licensee MDPI, Basel, Switzerland. This article is an open access article distributed under the terms and conditions of the Creative Commons Attribution (CC BY) license (https:// creativecommons.org/licenses/by/ $4.0 /)$.

\begin{abstract}
Cryptosporidium oocysts are known for being very robust, and their prolonged survival in the environment has resulted in outbreaks of cryptosporidiosis associated with the consumption of contaminated water or food. Although inactivation methods used for drinking water treatment, such as UV irradiation, can inactivate Cryptosporidium oocysts, they are not necessarily suitable for use with other environmental matrices, such as food. In order to identify alternative ways to inactivate Cryptosporidium oocysts, improved methods for viability assessment are needed. Here we describe a proof of concept for a novel approach for determining how effective inactivation treatments are at killing pathogens, such as the parasite Cryptosporidium. RNA sequencing was used to identify potential up-regulated target genes induced by oxidative stress, and a reverse transcription quantitative PCR (RT-qPCR) protocol was developed to assess their up-regulation following exposure to different induction treatments. Accordingly, RT-qPCR protocols targeting thioredoxin and Cryptosporidium oocyst wall protein 7 (COWP7) genes were evaluated on mixtures of viable and inactivated oocysts, and on oocysts subjected to various potential inactivation treatments such as freezing and chlorination. The results from the present proof-of-concept experiments indicate that this could be a useful tool in efforts towards assessing potential technologies for inactivating Cryptosporidium in different environmental matrices. Furthermore, this approach could also be used for similar investigations with other pathogens.
\end{abstract}

Keywords: Cryptosporidium; gene expression; oocyst; viability; RNA-Seq; RT-qPCR

\section{Introduction}

Environmentally transmitted pathogens represent a major public health concern worldwide. These pathogens, which can usually survive for prolonged periods in the external environment, are often transmitted to humans via contaminated environmental matrices, such as water and food [1]. Although methods for inactivating waterborne pathogens (e.g., UV irradiation) have been established, these are not always applicable to other matrices including various sorts of foods. Therefore, different technologies such as ozonation, high hydrostatic pressure, pulsed light, and thermal methods have been explored to inactivate microbial contaminants on environmental matrices such as fresh produce [2-5]. Such investigations require reliable methods for assessing the efficacy of inactivation technologies, especially for pathogens that are non-culturable or difficult to culture. Among such pathogens are environmentally transmitted protozoan parasites such as Cryptosporidium, Cyclospora, Toxoplasma, etc.; the present study focused on Cryptosporidium.

Cryptosporidium is a coccidian parasite responsible for cryptosporidiosis, a gastrointestinal disease manifesting mainly as watery diarrhea, nausea, vomiting, fatigue, and other signs and symptoms [6]. The watery diarrhea typical for cryptosporidiosis can sometimes be profuse and prolonged and result in dehydration and wasting. This may cause critical illness [7] and, due to the paucity of effective treatments, mortality rates may be high, 
especially for immunocompromised patients. Some species of Cryptosporidium, such as Cryptosporidium parvum, are zoonotic, with a wide range of potential hosts, although young ruminants are predominantly associated with human infections.

Humans acquire the infection through ingestion of the sporulated oocysts, each of which contain four sporozoites that invade the cells of intestinal epithelium. The highly robust and environmentally resistant oocysts are well suited for transmission via contaminated environmental matrices, such as water and food. Thus, transmission is often due to ingestion of water or food that has been contaminated with infectious oocysts. Outbreaks of cryptosporidiosis attributed to swimming pool or drinking water contamination have been frequently recorded [8], and foodborne outbreaks have also been documented [9,10]

Due to the complex nature of parasites, it has been challenging to develop sensitive in vitro methods for assessing their viability. The current "gold standard" method for viability testing of parasites is in vivo animal bioassay. Alternative in vitro techniques that have been explored include experimental infections in cell cultures, in vitro excystation, sporulation, vital dye inclusion/exclusion, propidium monoazide PCR (PMA-PCR), nucleic acid sequence-based amplification (NASBA), and reverse transcription quantitative PCR (RT-qPCR) [11], with each method having advantages and disadvantages. In vitro cell culture has been widely used for assessing the efficacy of Cryptosporidium inactivation by chlorination and UV irradiation among others [12-15]. It has been shown that the in vitro excystation method overestimated the viability of Cryptosporidium oocysts when, in particular, assessing the efficacy of UV inactivation, which was thus suggested to be less efficacious [16].

Although there are several published protocols for viability assessment of $C$. parvum based on RT-qPCR, there is no consensus on the best approach and there are different rationales for selecting a genetic marker. The present study aimed at developing a comparative RT-qPCR method that could be used for assessing the efficacy of inactivation technologies on pathogens, such as protozoan cysts and oocysts or robust bacterial or fungal spores, using C. parvum as a model organism. Potential target genes were identified by their up-regulation in response to oxidative stress.

\section{Materials and Methods}

\subsection{Parasites}

Cryptosporidium parvum IOWA strain oocysts were purchased from Bunch Grass Farm (Deary, ID, USA) and used within three months. The oocysts had been stored in PBS supplemented with antibiotics (1000 IU penicillin, $1000 \mu \mathrm{g}$ streptomycin), wrapped in cold gel pack, and shipped overnight by courier. An additional isolate of $C$. parvum oocysts was purified from calf feces that had been submitted to the Parasitology lab, Norwegian University of Life Sciences for diagnostic examination. The comparison of glycoprotein 60 (GP60) gene fragments from this isolate with the IOWA strain showed about $87 \%$ identity. The CryptoGenotyper tool [17] classified the IOWA strain as subtype IIaA17G2R1, whereas the isolate from the Parasitology lab was subtype IId.

\subsection{Experimental Setup}

In order to achieve the objective of the study, the experimental setup was designed to include four main sections including: (i) exploration of different induction approaches to stimulate upregulation of a range of genes; (ii) identification of these genes using RNA-Seq and differentially expressed gene (DEG) analysis; (iii) selection of appropriate targets and designing RT-qPCR protocols for their relative quantification; (iv) use of these protocols to determine viability of oocysts following exposure to different chemical and physical potential inactivation treatments. The experimental setup is summarized in Figure 1. 


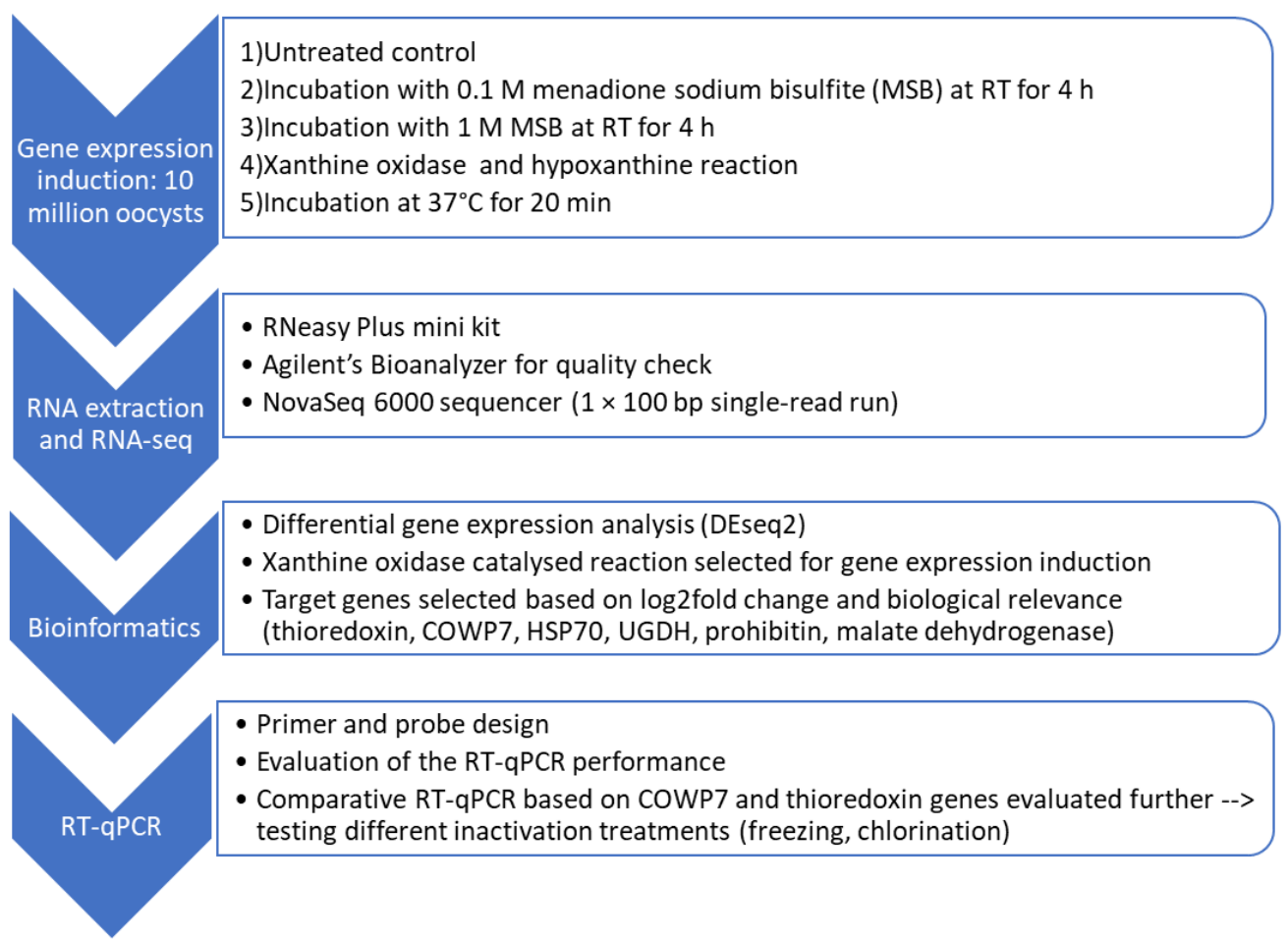

Figure 1. Flow chart indicating the 4 stages of the RT-qPCR method development.

\subsubsection{Identification of Inducible Target Genes Using RNA-Seq and DEG Analysis} Induction of Upregulation of Gene Expression

Five different gene-expression induction approaches were explored using, in brief: (a) two concentrations of menadione sodium bisulfite (MSB); (b) an enzymatic reaction composed of xanthine oxidase and hypoxanthine, and (c) heat shock at two different temperatures; see Table 1 for details. All chemicals used were purchased from SigmaAldrich, Norway. Each of the 5 induction groups contained four independent replicates of approximately 10 million C. parvum oocysts. Oocysts were pre-washed twice in water before being subject to the different induction treatments. A control group was stored refrigerated prior to RNA extraction.

Table 1. Description of the gene expression induction approaches explored for RNA-Seq analysis.

\begin{tabular}{|c|c|}
\hline Treatment & Brief Description \\
\hline $1 \mathrm{M}$ MSB & $\begin{array}{l}200 \mu \mathrm{L} \text { of oocysts (ca. } 10 \text { million) were mixed with } 500 \mu \mathrm{L} \text { of } 1 \mathrm{M} \mathrm{MSB} \text {, vortexed, then } \\
\text { held at room temperature for } 4 \mathrm{~h} \text {. The suspension was then washed } 3 \text { times with water } \\
\text { before total RNA extraction }\end{array}$ \\
\hline $0.1 \mathrm{M}$ MSB & $\begin{array}{l}200 \mu \mathrm{L} \text { of oocysts (ca. } 10 \text { million) were mixed with } 500 \mu \mathrm{L} \text { of } 0.1 \mathrm{M} \text { MSB, vortexed, } \\
\text { then held at room temperature for } 4 \text { h. The suspension was then washed } 3 \text { times with } \\
\text { water before total RNA extraction }\end{array}$ \\
\hline Xanthine oxidase and hypoxanthine & $\begin{array}{c}200 \mu \mathrm{L} \text { of oocysts (ca. } 10 \text { million) were vortexed and } 50 \mu \mathrm{L} \text { of xanthine oxidase } \\
(20 \mathrm{U} / \mathrm{mL} \text { ) added to the suspension. The suspension was brought up to } 500 \mu \mathrm{L} \text { with } \\
\text { PBS (pH 8.5) and incubated at } 37^{\circ} \mathrm{C} \text { for } 10 \text { min. Thereafter, } 500 \mu \mathrm{L} \text { of } 0.5 \mathrm{mM} \\
\text { hypoxanthine was added to the mixture, briefly vortexed and further incubated at } \\
37^{\circ} \mathrm{C} \text { for } 30 \text { min with the lids open. The sample was then washed } 3 \text { times with water } \\
\text { before total RNA extraction. }\end{array}$ \\
\hline Heat shock & $\begin{array}{c}200 \mu \mathrm{L} \text { of oocysts (ca. } 10 \text { million) were incubated at } 37^{\circ} \mathrm{C} \text { for } 20 \text { min. The sample was } \\
\text { then washed } 3 \text { times with water before total RNA extraction. }\end{array}$ \\
\hline Heat shock & $\begin{array}{c}200 \mu \mathrm{L} \text { of oocysts (ca. } 10 \text { million) were incubated at } 45^{\circ} \mathrm{C} \text { for } 20 \text { min. The sample was } \\
\text { then washed } 3 \text { times with water before total RNA extraction. }\end{array}$ \\
\hline Control & $\begin{array}{c}200 \mu \mathrm{L} \text { of oocysts (ca. } 10 \text { million) stored at refrigeration temperature were washed five } \\
\text { times with water before total RNA extraction. }\end{array}$ \\
\hline
\end{tabular}


RNA Extraction and Quality Assessment for RNA-Seq

The RNA extraction protocol for this study was based on RNeasy Plus Mini Kit (Qiagen, Oslo, Norway), with slight modifications to the lysis approach. Briefly, oocyst lysis was performed in a lysing matrix E tube (MP Biomedicals, Illkirch Cedex, France) to which $600 \mu \mathrm{L}$ of the RLT plus buffer was added, and the tube subjected to 2 cycles of bead-beating at $4 \mathrm{~m} / \mathrm{s}$ for $25 \mathrm{~s}$ with a 3-min pause on ice between cycles. The lysate was centrifuged at $12,000 \times g$ for $2 \mathrm{~min}$ and then added to the gDNA eliminator spin column before elution into $55 \mu \mathrm{L}$ of nuclease-free water and storage at $-20^{\circ} \mathrm{C}$.

RNA quality was assessed using an Agilent 2100 Bioanalyzer and the RNA 6000 Nano kit was used for sample preparation. The RNA integrity number (RIN) produced by the Bioanalyzer provides an indication of the RNA quality; RIN ranges from 1-10, where 10 indicates intact RNA. The RNA extracted from samples subjected to heat shock at $45{ }^{\circ} \mathrm{C}$ for 20 min did not produce RIN values and hence was not submitted for RNA-Seq.

RNA Sequencing (RNA-Seq)

The RNA samples were sequenced at a national technology core facility (Norwegian Sequencing Centre, Ullevål Hospital, Oslo, Norway). The RNA library preparation was performed using Truseq stranded RNA prep kit and sequenced in the NovaSeq SP flow cell with the NovaSeq 6000 sequencer. After indexing, all samples were sequenced in the same flow cell using single-read sequencing of $100 \mathrm{bp}$ and a sequencing depth of ca 20 million reads per sample.

\subsubsection{RT-qPCR Method Development}

The gene expression induction approach selected for the RT-qPCR method development was based on the oxidative stressor challenge as shown in Figure 2.

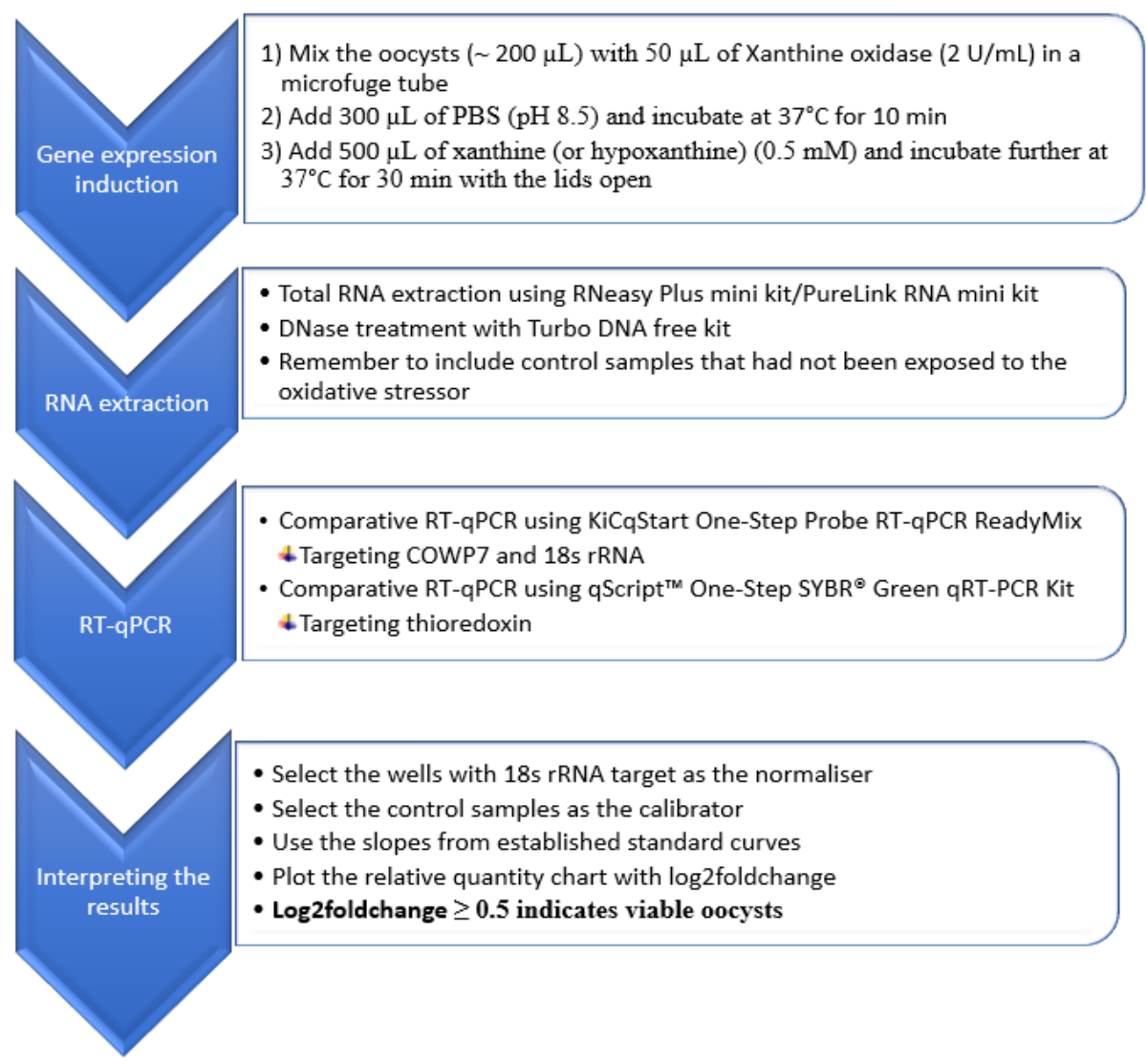

Figure 2. Flow chart representing the summary of the comparative RT-qPCR method for the assessment of viability of Cryptosporidium oocysts. 


\section{Target Genes and Primers}

Based on the differentially expressed genes (DEG) analysis (see Section 2.3.2), six different target genes were selected for further testing using RT-qPCR. These genes included COWP7, type 3 malate dehydrogenase, thioredoxin, prohibitin, heat shock protein 70 (HSP70), and UDP-glucose 6-dehydrogenase (UGDH). In order to evaluate the targets identified by the DEG analysis by RT-qPCR, appropriate primers were designed in Geneious Prime, with intron-spanning sites included where possible (Table 2). In addition to the differentially expressed target genes, $18 \mathrm{~S}$ rRNA was selected as the reference gene to normalize variation between samples.

\section{RNA Extraction for the RT-qPCR Method}

The PureLink RNA mini kit (Thermo Fisher Scientific, Oslo, Norway) was employed for total RNA extraction in the RT-qPCR method development. This kit was used here for pragmatic reasons; it was available in the lab and had demonstrated no difference compared with the RNeasy Plus Mini Kit (Table S1). Briefly, the sample containing approximately 2 million oocysts of $C$. parvum $(0.3 \mathrm{~mL})$ was mixed with $0.6 \mathrm{~mL}$ of the lysis buffer containing $40 \mathrm{mM}$ dithiothreitol in a lysing matrix $\mathrm{E}$ tube and subjected to bead-beating (two cycles of $4 \mathrm{~m} / \mathrm{s}$ for $25 \mathrm{~s}$ with $3 \mathrm{~min}$ pause on ice in between the cycles). The lysate was then centrifuged at $12,000 \times g$ for 2 min and the supernatant transferred to a new collection tube and purified according to the kit's instruction. RNA was eluted in $50 \mu \mathrm{L}$ RNase free water before DNase treatment using Turbo DNA free kit (Thermo Fisher Scientific, Norway) and stored at $-20{ }^{\circ} \mathrm{C}$ until RT-qPCR analysis.

\section{Reverse Transcription Quantitative PCR (RT-qPCR) \\ One-Step SYBR Green RT-qPCR}

RT-qPCR was performed in a total volume of $20 \mu \mathrm{L}$, which included $10 \mu \mathrm{L}$ of One-Step SYBR Green master mix, $0.4 \mu \mathrm{L}$ of the qScript RT-mix, $0.5 \mu \mathrm{M}$ of each primer, and $2 \mu \mathrm{L}$ of RNA template. The reaction assembly was performed according to the instructions provided with the master mix (Quantabio, Beverly, CA, USA) and thermal cycling and fluorescence measurement were done in Stratagene Mx3005P qPCR instrument (Agilent Technologies, Matriks As, Oslo, Norway). The thermal profile of the reaction was as follows: cDNA synthesis at $50{ }^{\circ} \mathrm{C}$ for $10 \mathrm{~min}$, initial denaturation at $95{ }^{\circ} \mathrm{C}$ for $5 \mathrm{~min}$ followed by 45 cycles of denaturation at $95^{\circ} \mathrm{C}$ for $15 \mathrm{~s}$, and annealing/extension at $60{ }^{\circ} \mathrm{C}$ for $1 \mathrm{~min}$. Additionally, a melt-curve analysis step was included, with a gradual increase of temperature from $65^{\circ} \mathrm{C}$ to $95^{\circ} \mathrm{C}$ and fluorescence data collected every $0.1^{\circ} \mathrm{C}$.

One-Step Probe RT-qPCR

In addition to the SYBR Green RT-qPCR, a probe-based One-step RT-qPCR was tested for the COWP7 target. The reaction was performed in a total volume of $20 \mu \mathrm{L}$ that contained $10 \mu \mathrm{L}$ of KiCqStart ${ }^{\circledR}$ One-Step Probe RT-qPCR ReadyMix, $0.5 \mu \mathrm{M}$ of each primer, $0.25 \mu \mathrm{M}$ probe, and $2 \mu \mathrm{L}$ of the RNA template. The 18S rRNA target was detected and quantified using $0.6 \mu \mathrm{M}$ of the forward primer (1:1 combination of JF1 and JF2) and reverse primer (JR) and $80 \mathrm{nM}$ of the probe (JT2). Thermal cycling and fluorescence measurement were done in Stratagene Mx3005P qPCR instrument (Agilent Technologies). The thermal profile of the reaction included cDNA synthesis at $50{ }^{\circ} \mathrm{C}$ for $10 \mathrm{~min}$, initial denaturation at $95{ }^{\circ} \mathrm{C}$ for $3 \mathrm{~min}$ followed by 45 cycles of denaturation at $95^{\circ} \mathrm{C}$ for $15 \mathrm{~s}$, annealing at $60^{\circ} \mathrm{C}$ for $1 \mathrm{~min}$, and extension at $72{ }^{\circ} \mathrm{C}$ for $30 \mathrm{~s}$.

Standard curves were prepared to evaluate the linearity and efficiency of each primer pair. An additional test was conducted to compare xanthine and hypoxanthine as the substrate in the oxidative stress induction.

\subsubsection{Evaluation of the RT-qPCR Method}

The RT-qPCR method was evaluated for its applicability in the differentiation of viable and inactivated oocysts using different inactivation treatments. The main steps of the RT-qPCR are summarized in the flow chart presented in Figure 2. 
Table 2. Oligos employed to evaluate the validity of selected target genes in the development of new RT-qPCR method to assess the viability of Cryptosporidium oocysts.

\begin{tabular}{|c|c|c|c|c|c|}
\hline Target Gene & Forward Primer $\left(5^{\prime} \rightarrow 3^{\prime}\right)$ & Reverse Primer $\left(5^{\prime} \rightarrow 3^{\prime}\right)$ & Probe $\left(5^{\prime} \rightarrow 3^{\prime}\right)$ & Product Size (bp) & Locus Tag (Ref.) \\
\hline COWP7 & CTATGGGATTCAATTTCGAAGTTCC & СССААТАСААААТСТGСТАСТТССА & ATGGAATATCATCATCСССТCAGCAA & 97 & cgd4_500 \\
\hline Thioredoxin & GAAAAGCTGAACCTCGCATTCG & CGTCCCGTGGTCAATGCAATAA & NA & 134 & cgd7_4080 \\
\hline Prohibitin & CCTTTTAGGTGCAATCGGAACA & CATGGGAGGAAGAAGTGGGTAC & NA & 141 & cgd7_4240 \\
\hline $\mathrm{MDH}$ & TCCTCTAGATGCGATGGTTTACTAC & ССАССТАСАACAATGGCTGATACA & NA & 162 & cgd7_470 \\
\hline HSP70 & AGCCCGTATGAGTACAGAAGACT & GCCTGTGCCAAGAACCCTAAGA & NA & 168 & cgd4_3270 \\
\hline $18 \mathrm{~S}$ rRNA & $\begin{array}{c}\text { JF1: AAGCTCGTAGTTggatTTCTGJF2: } \\
\text { AAGCTCGTAGTTaatcTTCTG }\end{array}$ & JR: TAAGGTGCTGAAGGAGTAAGG & JT2: TCAGATACCGTCGTAGTCT & 434 & [18] \\
\hline
\end{tabular}




\subsubsection{Inactivation of Cryptosporidium Oocysts}

In order to assess the applicability of the RT-qPCR method, physical and chemical inactivation approaches that had been previously evaluated using mice bioassay $[19,20]$, were used to determine whether the method developed here could be used to evaluate inactivation efficacy. Accordingly, Cryptosporidium oocysts were inactivated by heating at $80^{\circ} \mathrm{C}$ (on heat block) for $3 \mathrm{~min}$ and incubated at room temperature for $3 \mathrm{~h}$ prior to RNA extraction. This was considered sufficient for complete inactivation of the oocysts and therefore used to prepare different proportions of live/inactivated oocysts as described in Section 2.2.3.2. Other inactivation treatments investigated in this study included heating at $60^{\circ} \mathrm{C}$ for $2 \mathrm{~min}$, freezing at $-20^{\circ} \mathrm{C}$ for $2 \mathrm{~h}, 24 \mathrm{~h}$, and $48 \mathrm{~h}$. In addition to thermal inactivation, chemical treatment was assessed by subjecting oocysts to $4 \mathrm{mg} / \mathrm{L}$ and $0.2 \mathrm{mg} / \mathrm{L}$ free chlorine concentrations for $30 \mathrm{~min}$.

\subsubsection{Distinguishing between Viable and Inactivated Oocysts Using the New} RT-qPCR Method

The new RT-qPCR method was evaluated for its ability to discriminate between different proportions of viable and inactivated oocysts by analyzing samples containing different proportions of viable and inactivated oocysts. In brief, the oocyst mixtures (containing viable/inactivated oocysts (heated at $80^{\circ} \mathrm{C}$ for $3 \mathrm{~min}$ ) in the following proportions: $0 / 100$, $1 / 99,10 / 90,100 / 0 \%$ ) were exposed to an inactivation regime as described in Section 2.2.3.1. Then the oocysts were exposed to xanthine oxidase catalyzed oxidative stressor before RNA extraction. RT-qPCR targeting thioredoxin, COWP7, and 18S rRNA was used to determine relative quantity of thioredoxin and COWP7 genes from exposure to the oxidative stressor. Controls that contained the same proportion of viable/inactivated oocysts, but had not been exposed to the oxidative stressor, were included in each run.

\subsection{Statistical Analysis}

\subsubsection{Data Pre-Processing and Mapping}

Raw sequence data (fastq files) from the RNAseq were trimmed for adapter sequences and low quality reads (having phred score <33) by using trimommatic 0.39 (http:/ / www.us adellab.org/cms/?page=trimmomatic, accessed on 26 February 2021) and assessed for quality by using FASTQC tool. The trimmed reads were mapped to the reference genome of $C$. paroum IOWA II obtained from CryptoDB release 46 (https: / / cryptodb.org/common/downloads/ release-46/CparvumIowaII/fasta/data/CryptoDB-46_CparvumIowaII_Genome.fasta, accessed on 26 February 2021) using STAR version 2.5 [21]. In addition, the Salmon tool [22] was applied for quasi-mapping of the trimmed reads against the annotated transcript of C. parvum IOWA II available from the CryptoDB release 46 (https: / / cryptodb.org/common/download s/release-46/CparvumIowaII/fasta/data/CryptoDB-46_CparvumIowaII_AnnotatedTranscr ipts.fasta, accessed on 26 February 2021).

\subsubsection{Differential Gene Expression Analysis}

The mapped reads were counted against the recently updated genome annotation file obtained from CryptoDB release 46 (https: / / cryptodb.org/common/downloads/release46/CparvumIowaII/gff/data/CryptoDB-46_CparvumIowaII.gff, accessed 26 on February 2021). Gene counts table was prepared using featureCounts [23], which was then used as an input for the differential expression analysis with the R-based tool, DESeq2 [24].

In addition to the gene-based differential expression analysis, a transcript-based differential expression analysis was performed on the transcript abundance output obtained from the Salmon tool and further analyzed with DESeq2 in R. The differential expression analysis output contained the list of genes with their $\log 2$ fold change and associated $p$-values. The results of the DEG analysis were visualized using principal component analysis (PCA) plots and MA-plots. 


\section{Results}

\subsection{RNA-Seq Analysis}

The sequencing reads were of high quality as indicated by the average Phred score of 36. The RNA-Seq data have been submitted to the sequence read archive of NCBI and are available for public use with the accession number PRJNA669334 (http:/ / www.ncbi.nlm.n ih.gov/bioproject/669334, accessed on 7 July 2021). The overall alignment rate of the reads against the reference genome was $>96 \%$ whereas the alignment rate of the reads against the reference transcriptome was $>89 \%$ (Table S2).

Differentially expressed genes (DEG) analysis of the RNA-Seq data revealed that, as shown by the principal component analysis (PCA), two groups of samples were clearly separated from the others that grouped together (Figure 3). The PCA plot shows that the samples subjected to oxidative stressor from the enzymatic reaction of xanthine oxidase and hypoxanthine, as well as those subjected to heat shock, were placed distinctly separate from one another and from the other three groups. The samples treated with menadione sodium bisulfite (MSB) showed no difference from the control samples.
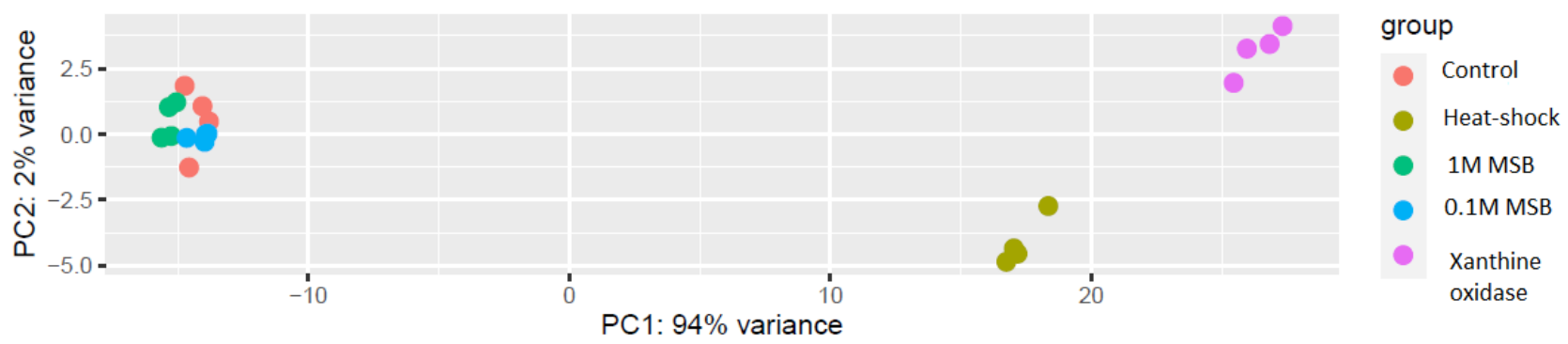

Figure 3. PCA of the RNA-Seq data after rlog transformation.

The MA plot (Figure S1) for the RNA-Seq data also showed differences in gene expression between the sample groups, indicating that MSB-treated samples and untreated control samples had similar gene expression levels, as shown by the distribution of genes around the horizontal axis. In contrast, samples subjected to heat shock or to the xanthine oxidase catalyzed reaction had clearly visible differences in gene expression levels compared with the untreated control.

The DEG analysis showed that many genes were differentially expressed in response to the oxidative stress (Dataset S1). In order to develop an RT-qPCR method, six target genes were selected based on their log2fold change and their general biological relevance in the oxidative stress response of cells (Table S3).

\subsection{RT-qPCR Method Development}

The performance of each primer pair (i.e., efficiency and linearity) was well within the acceptable ranges. The standard curve prepared to assess the efficiency and linearity of the RT-qPCR based on the COWP7 gene is presented as an example (Figure S2).

Preliminary experiments investigating the six different target genes selected for the RTqPCR method development showed that all were upregulated following oxidative stress, as indicated by consistently lower $C_{q}$ values than those of untreated controls (Table 3). This confirmed the results obtained from the DEG analysis of the RNA-Seq data.

Among the six target genes evaluated, COWP7 and thioredoxin were selected for further evaluation. The intron-spanning primer pair designed for the detection of COWP7 showed no amplification from genomic DNA in the absence of DNase treatment, confirming the reliability of comparative quantitation of the transcript among the different groups of samples. For thioredoxin, the DNase treatment of the RNA sample with Turbo DNA-free kit was effective, as no amplification was detected in the absence of the reverse transcriptase enzyme.

The comparison of xanthine and hypoxanthine as a substrate for the xanthine oxidase catalyzed reaction showed no significant difference. However, samples treated with 
xanthine had consistently lower $\mathrm{C}_{\mathrm{q}}$ values when tested with COWP7 and thioredoxin (Figure S3). Therefore, xanthine was employed for the rest of the RT-qPCR evaluation.

Table 3. Comparative quantitative analysis of selected target genes using $18 \mathrm{~S}$ rRNA as the reference gene (normalizer).

\begin{tabular}{ccccccccc}
\hline \multirow{2}{*}{ Target Gene } & \multicolumn{4}{c}{ Test Samples $\left(\mathbf{C}_{\mathbf{q}}\right)^{\mathbf{a}}$} & \multicolumn{3}{c}{ Control Samples $\left(\mathbf{C}_{\mathbf{q}}\right)$} & \multicolumn{2}{c}{ Log2FC } \\
\cline { 2 - 7 } & T1 & T2 & T3 & Mean & C1 & C2 & Mean & \\
\hline COWP7 & 28.7 & 28.9 & 28.3 & 28.6 & 34.6 & 35.1 & 34.8 & 6.34 \\
Thioredoxin & 23.4 & 23.5 & 23.2 & 23.3 & 27.3 & 27.3 & 27.3 & 4.08 \\
UGDH & 25.1 & 25.2 & 25.1 & 25.1 & 29.6 & 29.4 & 29.5 & 4.49 \\
MDH & 22.7 & 22.6 & 22.6 & 22.6 & 26.5 & 26.7 & 26.6 & 4.11 \\
HSP70 & 24.6 & 24.0 & 24.5 & 24.3 & 28.9 & 28.6 & 28.7 & 4.54 \\
Prohibitin & 26.0 & 25.8 & 25.9 & 25.9 & 30.0 & 30.1 & 30.0 & 4.28 \\
\hline
\end{tabular}

a Samples subjected to oxidative stressor challenge using xanthine oxidase and xanthine reaction. ${ }^{\mathrm{b}}$ Log2fold change.

Compared with heat shock $\left(45^{\circ} \mathrm{C}\right.$ for $20 \mathrm{~min}$ ), the xanthine oxidase-catalyzed stressor challenge resulted in increased gene expression. Although the heat shock also induced higher gene expression than in controls, it was considerably lower than when oocysts were exposed to the oxidative stress. The difference was about $3 C_{q}$, which amounts to approximately 8.5-fold (Figure 4).

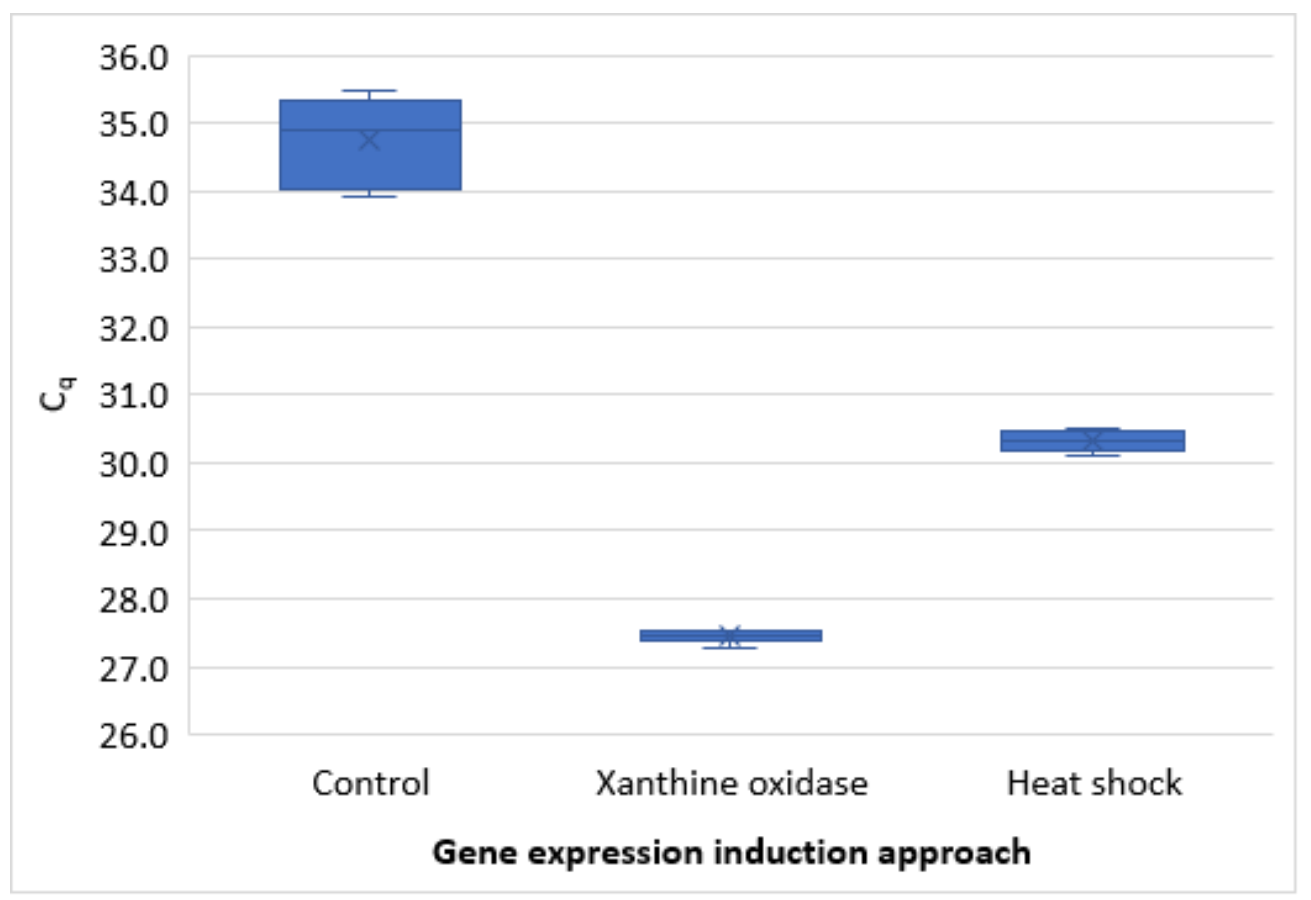

Figure 4. Comparison of gene expression induced by heat shock $\left(45^{\circ} \mathrm{C}\right.$ for $\left.20 \mathrm{~min}\right)$ with that induced by oxidative stressor challenge catalyzed by xanthine oxidase.

\subsection{Evaluation of the RT-qPCR Method}

The thioredoxin RT-qPCR results indicated that the level of gene expression was proportionally related to the number of viable oocysts in the sample (Table 4). Induction of the oxidative stress response resulted in significantly more transcripts than that of the respective control that had not been exposed to the oxidative stressor.

The RT-qPCR protocol was further tested on a different isolate of C. parvum that had been purified from a sample delivered for diagnosis at the Parasitology lab, Norwegian University of Life Sciences. The results with this isolate indicated that the protocol was applicable to another Cryptosporidium isolate, in addition to the IOWA strain used for the 
development of the method. The results of the comparative RT-qPCR showed that the sample subjected to oxidative stress had $\log 2$ foldchange of 3 to 3.9 .

Table 4. Evaluation of the RT-qPCR targeting thioredoxin by using mixtures of viable and inactivated oocysts of C. parvum.

\begin{tabular}{|c|c|c|c|c|c|}
\hline & \multicolumn{2}{|c|}{ Sample Preparation } & \multicolumn{2}{|c|}{ Induction Treatment Group } & \multirow[b]{2}{*}{$\Delta \mathrm{C}_{\mathrm{q}}$} \\
\hline & Viable (\%) & Inactivated (\%) & $\begin{array}{l}\text { Control } \\
\mathrm{C}_{\mathrm{q}} \text { Value }\end{array}$ & $\begin{array}{c}\text { Oxidative Stress } \\
\mathrm{C}_{\mathrm{q}} \text { Value }\end{array}$ & \\
\hline \multirow[t]{2}{*}{ Sample 1} & 100 & 0 & 29.9 & 25.6 & 4.3 \\
\hline & 100 & 0 & 30.0 & 25.8 & 4.2 \\
\hline \multirow[t]{2}{*}{ Sample 2} & 10 & 90 & 34.9 & 29.6 & 5.3 \\
\hline & 10 & 90 & 33.6 & 28.6 & 5 \\
\hline \multirow[t]{2}{*}{ Sample 3} & 1 & 99 & $\mathrm{No}_{\mathrm{q}}$ & 32.0 & NA \\
\hline & 1 & 99 & $36.4^{1}$ & 31.5 & 4.9 \\
\hline \multirow[t]{2}{*}{ Sample 4} & 0 & 100 & $\mathrm{No} \mathrm{C}_{\mathrm{q}}$ & $\mathrm{No} C t$ & NA \\
\hline & 0 & 100 & 35.9 & 36.0 & -0.1 \\
\hline
\end{tabular}

The method was also evaluated for its use in testing the efficacy of some of the physical and chemical means of inactivation of the oocysts. Although oocysts were completely inactivated following freezing $\left(-20^{\circ} \mathrm{C}\right)$ for $24 \mathrm{~h}$ and $48 \mathrm{~h}$, oocysts frozen for only $2 \mathrm{~h}$ were apparently not inactivated. This was indicated by the oocysts' response to the oxidative stressor challenge, with a mean $C_{q}( \pm S D)$ of $28.5 \pm 0.1$ for these oocysts. This is very similar to control oocysts that had not been frozen with mean $C_{q}( \pm S D)$ of $28.6 \pm 0.3$ (Table 5).

Table 5. The effect of extreme temperature on the viability of Cryptosporidium oocysts.

\begin{tabular}{|c|c|c|c|c|c|}
\hline \multirow{2}{*}{\multicolumn{2}{|c|}{ Treatment Condition }} & \multicolumn{2}{|c|}{$\mathrm{C}_{\mathrm{q}}$ Value COWP7 } & \multicolumn{2}{|c|}{$\mathrm{C}_{\mathrm{q}}$ Value Thioredoxin } \\
\hline & & No Oxidative Stress & Oxidative Stress & No Oxidative Stress & Oxidative Stress \\
\hline \multirow[t]{4}{*}{$-20^{\circ} \mathrm{C}$ for $2 \mathrm{~h}$} & Replicate 1 & 34.1 & 28.4 & 26.9 & 24.6 \\
\hline & Replicate 2 & 34.3 & 28.5 & 26.7 & 23.6 \\
\hline & Replicate 3 & 33.7 & 28.4 & 26.9 & 23.9 \\
\hline & Mean $\mathrm{C}_{\mathrm{q}} \pm \mathrm{SD}$ & $34 \pm 0.3$ & $28.5 \pm 0.1$ & $26.8 \pm 0.1$ & $24.0 \pm 0.5$ \\
\hline \multirow[t]{4}{*}{$-20^{\circ} \mathrm{C}$ for $24 \mathrm{~h}$} & Replicate 1 & 33.7 & 35.3 & 30.2 & 30.2 \\
\hline & Replicate 2 & 33.9 & 34.7 & 30.4 & 30.0 \\
\hline & Replicate 3 & 33.6 & 33.7 & 30.2 & 29.1 \\
\hline & Mean $\mathrm{C}_{\mathrm{q}} \pm \mathrm{SD}$ & $33.7 \pm 0.2$ & $34.6 \pm 0.8$ & $30.2 \pm 0.1$ & $29.7 \pm 0.6$ \\
\hline \multirow[t]{4}{*}{$-20{ }^{\circ} \mathrm{C}$ for $48 \mathrm{~h}$} & Replicate 1 & 36.6 & 37.8 & 30.7 & 30.8 \\
\hline & Replicate 2 & 37.9 & 37.6 & 30.7 & 32.8 \\
\hline & Replicate 3 & 35.1 & 36.4 & 29.9 & 31.2 \\
\hline & Mean $\mathrm{C}_{\mathrm{q}} \pm \mathrm{SD}$ & $36.5 \pm 1.4$ & $37.3 \pm 0.7$ & $30.4 \pm 0.5$ & $31.6 \pm 1.1$ \\
\hline \multirow[t]{4}{*}{$60^{\circ} \mathrm{C}$ for $2 \mathrm{~min}$} & Replicate 1 & 37.8 & 36.7 & 31.8 & 30.8 \\
\hline & Replicate 2 & 37.7 & 35.1 & 32.9 & 31.0 \\
\hline & Replicate 3 & No $C_{q}$ & 35.7 & 31.7 & 30.8 \\
\hline & Mean $\mathrm{C}_{\mathrm{q}} \pm \mathrm{SD}$ & $37.8 \pm 0.1$ & $35.8 \pm 0.8$ & $32.1 \pm 0.7$ & $30.9 \pm 0.1$ \\
\hline \multirow[t]{3}{*}{$80{ }^{\circ} \mathrm{C}$ for $3 \mathrm{~min}$} & Replicate 1 & No $C_{q}$ & No $C_{q}$ & No C $_{q}$ & No Cq \\
\hline & Replicate 2 & No $C_{q}$ & No $C_{q}$ & 35.9 & 36.0 \\
\hline & Mean $\mathrm{C}_{\mathrm{q}} \pm \mathrm{SD}$ & NA & NA & NA & NA \\
\hline \multirow{4}{*}{ Control $^{\mathrm{a}}$} & Replicate 1 & 34.6 & 28.7 & 27.3 & 23.4 \\
\hline & Replicate 2 & 35.1 & 28.9 & 27.3 & 23.5 \\
\hline & Replicate 3 & ND & 28.3 & ND & 23.2 \\
\hline & Mean $\mathrm{C}_{\mathrm{q}} \pm \mathrm{SD}$ & $34.9 \pm 0.4$ & $28.6 \pm 0.3$ & 27.3 & $23.4 \pm 0.2$ \\
\hline
\end{tabular}

a Not exposed to the low/high temperature; ND Not done; NA Not applicable.

Furthermore, oocysts that had been heated at $60{ }^{\circ} \mathrm{C}$ for 2 min showed some, but incomplete, inactivation, compared with the control oocysts. Although the mean $\mathrm{C}_{\mathrm{q}}$ of these oocysts was lower than that of their corresponding control (not exposed to the oxidative stressor), it was markedly higher than that of the test control oocysts that had not been exposed to the elevated temperature (Table 5). This means that following exposure to this potential thermal-inactivation treatment, some oocysts were still able to respond 
to the oxidative stressor challenge with gene up-regulation. However, oocysts exposed to $80^{\circ} \mathrm{C}$ for $3 \mathrm{~min}$ seem to be completely inactivated as the RT-qPCR results showed no amplification for the COWP7 target. However, some traces of amplification could be detected from the thioredoxin target (Table 5).

Chemical treatment of oocysts with 0.2 and $4 \mathrm{mg} / \mathrm{L}$ free chlorine for $30 \mathrm{~min}$ at room temperature did not affect the viability of the oocysts (Figure S4). The comparative RTqPCR results show the difference between oocysts treated with bleach and those stored at $-20{ }^{\circ} \mathrm{C}$ for $24 \mathrm{~h}$.

\section{Discussion}

In this study, we have developed and evaluated a RT-qPCR method that could be useful for differentiating viable, potentially infectious, oocysts of C. parvum from inactivated ones. The method development approach was guided by the biological assumption that viable oocysts would respond actively to stressors with up-regulation of specific genes. Thus, as changes in gene expression would not be expected in dead oocysts subjected to exposure to stressors, this could be an indicator that the oocysts were viable. Rigorous testing by RNA-Seq analysis, and with complementary results obtained with the RT-qPCR, indicated this to be the case.

The reactions catalyzed by xanthine oxidase, as shown in (Figure S5), were further explored to compare xanthine and hypoxanthine as the substrate. As oxidation of xanthine produces uric acid, which can also act as a pro-oxidant [25] we assumed that the use of xanthine as substrate might result in greater stimulation of gene expression. Indeed, the results of the comparative experiment showed a stronger response for xanthine than hypoxanthine, although the difference was relatively small. Nevertheless, for the experiments that involved xanthine as substrate, the precision of the quantification was superior.

RNA-Seq analysis revealed several DEGs in response to the oxidative stressor challenge. Although RNA-Seq have been used for transcriptomic analysis of the developmental stages of Cryptosporidium [26-28], to the best of our knowledge, this technique has not previously been exploited for the purpose of developing methods for viability assessment of Cryptosporidium oocysts.

Among the six target genes evaluated, COWP7 and thioredoxin were selected for further evaluation. This was due to the high log fold change for each gene. COWP7 was also selected because of the putative role of COWP genes in protecting the oocysts and surviving environmental stresses [29]. In addition, COWP7 was the only gene among the six examined that contains introns, making it a suitable candidate for RT-qPCR method. Furthermore, thioredoxin was selected on the basis of its potential role in the oxidative stress response, as it is a well-known antioxidant enzyme that protects cells from cytotoxicity elicited by oxidative stress [30].

The most commonly used method for gene-expression induction prior to RNA extraction followed by RT-qPCR for Cryptosporidium viability testing is heating the oocysts at $45{ }^{\circ} \mathrm{C}$ for $20 \mathrm{~min}$ so that the sensitivity would be improved and HSP70 has been the target of choice [20,31,32]. However, in our work, exposure of oocysts to $45^{\circ} \mathrm{C}$ for $20 \mathrm{~min}$ resulted in poor quality RNA, probably due to degradation, which could not be used for RNA-Seq. Although these samples were not suitable for RNA-Seq, the RT-qPCR results showed that gene expression could be induced by heat shock, but was about 8-fold lower than the present approach of exposure to oxidative stress.

In contrast, another study argued that the ideal viability marker should not be altered by an external stressor and hence suggested the use of CP2 over HSP70 [33]. Others have suggested using the ratio of mRNA to DNA for the assessment of viability following heat-induction [32]. Collectively, these results indicate that RT-qPCR-based methods could be a rapid, sensitive, and reliable estimate of the viability of parasites when selection of target genes, designing the experimental setup, and interpreting the results are optimized.

The approach that we explored involved induction of gene expression by exposure to stressors and comparison of the relative quantity of expression of relevant genes in 
exposed and non-exposed control samples (normalized against reference genes to correct for artificial differences between the samples). This approach avoids the problem of overestimation of viability due to detection of residual RNA in inactivated oocysts, as has been previously reported [34,35].

Through thorough evaluation of the RT-qPCR method using oocysts exposed to various inactivating treatments, we have shown that this method may be a useful tool for assessing the efficacy of different treatments at inactivating Cryptosporidium oocysts. Furthermore, by using the $18 \mathrm{~S}$ rRNA gene as a normalizer and inclusion of untreated control samples we have shown that this approach may enable precise estimation of log reductions in oocyst viability due to different inactivation treatments.

The inactivation efficacy of freezing at $-20{ }^{\circ} \mathrm{C}$ was time dependent, with longer storage duration resulting in more effective inactivation; although oocyst viability was not affected by freezing for $2 \mathrm{~h}$, complete inactivation was seen after $24 \mathrm{~h}$. These findings corroborate the results reported by Fayer and Nerad (1996), in which the mouse infectivity assay was employed to test the effect of low temperatures on the viability of oocysts. According to the results of that study, mice fed with the oocysts stored at $-20^{\circ} \mathrm{C}$ for $1 \mathrm{~h}$, $3 \mathrm{~h}, 5 \mathrm{~h}$, and $8 \mathrm{~h}$ were infected, as indicated by the histological examination of the colon, ileum, and cecum of the mice showing the parasite's developmental stages, but mice that received oocysts frozen at $-20^{\circ} \mathrm{C}$ for $24 \mathrm{~h}$ and $168 \mathrm{~h}$ were not infected [19].

According to the RT-qPCR method presented here, chemical treatment of oocysts with 0.2 and $4 \mathrm{mg} / \mathrm{L}$ free chlorine for $30 \mathrm{~min}$ at room temperature did not affect the viability of the oocysts. It has long been known that Cryptosporidium oocysts are incredibly resistant to chlorination $[36,37]$. Thus, although the results are not surprising, they demonstrate and confirm that the new RT-qPCR method could be a useful method for determining the inactivation efficiency of different chemical treatments.

Complete inactivation of the oocysts after heating at $80{ }^{\circ} \mathrm{C}$ for $3 \mathrm{~min}$ agrees with the findings of Travaillé et al., (2016) [20], in which mice fed with oocysts heated at $80{ }^{\circ} \mathrm{C}$ for 2 min were not infected. In addition, Travaillé et al., (2016) reported that mRNA could not be detected when mRNA extraction was performed after incubation of the sample at room temperature for $1 \mathrm{~h}$ [20]. However, in contrast, our results were different, as mRNA was detected even after incubation of the heat-treated oocysts at room temperature for $3 \mathrm{~h}$. This could be due to differences in the stability of different types of mRNA, as it has been shown that HSP70 mRNA is more stable than $\beta$-tubulin mRNA [34]. Indeed, in the present study, it was shown that thioredoxin was more likely to be detected than COWP7.

The novelty of the present RT-qPCR method lies in the application of an oxidative stressor challenges to assess the metabolic activity among populations of oocysts, as the method exploits the relative quantification of genes expressed in response to oxidative stress; inactivated oocysts will not demonstrate alterations in gene expression. This differs substantially from the assumption used in various other efforts to develop viability assays, where mRNA detection is used as an indicator of viability. However, as we see here, and has also been reported previously [34], mRNA can be detected in inactivated oocysts, and therefore does not adequately differentiate between viable and inactivated oocysts.

However, the present study is not without limitations and further validation should be performed, including comparison with the "gold standard" method (i.e., mouse infectivity bioassay). As we were unable to perform bioassays, the in-house evaluation of the RT-qPCR method was designed to include the parameters of inactivation treatments that had been assessed by bioassay in previously published work $[19,20]$.

Another limitation of the present RT-qPCR method is that the sensitivity of the method is poor. This could be due to the mild lysis protocol used during the RNA extraction. This means that the method is not suitable for assessing the viability of oocysts detected in naturally contaminated water samples, or other environmental matrices, where usually only low numbers of contaminating oocysts are detected. However, further optimization may improve the sensitivity. Nevertheless, the present method's value will lie in being able to assess the efficacy of potential inactivation procedures, as high numbers of oocysts are 
used for such investigations. The lysis approach used in the RNA extraction protocol was the same as that used for the RNA-Seq analysis, which is specifically intended to result in high-quality RNA. However, such high-quality RNA might not be necessary for RT-qPCR. Therefore, optimization of the RNA extraction protocol to increase RNA yield, and thus the sensitivity of the RT-qPCR, may be a pertinent approach. However, it is important that the RNA yield is not achieved at the expense of the quality required for the RT-qPCR protocol.

In conclusion, the findings of the present study showed that RNA-Seq and DEG analysis are very useful tools in the identification of targets when developing RT-qPCR based methods for viability testing. It was also shown that oxidative stressors are suitable for inducing mRNA expression of selected genes in Cryptosporidium oocysts. Evaluation of the present RT-qPCR method showed that it could be a reliable, rapid, and cost-effective alternative used for testing the efficacy of different inactivation treatments on Cryptosporidium oocysts. Moreover, the present approach to method development could also be applied to other environmental pathogens.

Supplementary Materials: The following are available online at https://www.mdpi.com/article/1 0.3390/microorganisms9071463/s1, Figure S1: The MA-plot representing gene expression differences following (A) heat shock treatment $\left(37^{\circ} \mathrm{C}\right.$ for $20 \mathrm{~min}$ ), (B) xanthine oxidase and hypoxanthine reaction, (C) 0.1M MSB treatment, (D) 1M MSB treatment compared to the untreated control group, Figure S2: The standard curve prepared by using 5-fold serial dilution of RNA extracted from 2 million oocysts of C. parvum, Figure S3: Comparison of xanthine and hypoxanthine as the substrate in the oxidative stress challenge as indicated by RT-qPCR results for COWP7 (top) and thioredoxin (bottom) tests, Figure S4: Relative quantity chart for Thioredoxin RT-qPCR test on samples frozen at $-20^{\circ} \mathrm{C}$ for $24 \mathrm{~h}$, treated with $4 \mathrm{mg} / \mathrm{L}$ free chlorine, and $0.2 \mathrm{mg} / \mathrm{L}$ free chlorine for $30 \mathrm{~min}(18 \mathrm{~s}$ rRNA was used as the reference gene), Figure S5: Xanthine oxidase catalyzed reactions, Table S1: The assessment of quality of RNA, using Agilent's Bioanalyzer, extracted from 10 million oocysts of $C$. parvum under different conditions and kits, Table S2: The overall alignment rate of trimmed reads against the reference genome and transcriptome of Cryptosporidium parvum, Table S3: List of potential target genes selected for the assessment of the viability of Cryptosporidium oocysts using the novel comparative RT-qPCR method. Dataset S1: DEG analysis.

Author Contributions: T.T.T.: conceived research, designed research, performed research, analysed data, wrote the original draft. K.R.T.: acquired funding, administered the project, designed research, wrote the paper. L.J.R.: acquired funding, designed research, supervised the research activities, wrote the paper. All authors have read and agreed to the published version of the manuscript.

Funding: This work was funded by the Norwegian Research Council (grant no. 267430). The funder had no role in the design of the study, data collection, writing of the manuscript and in the decision to submit this article for publication.

Institutional Review Board Statement: Not applicable.

Informed Consent Statement: Not applicable.

Data Availability Statement: The RNA-Seq data is available for public use at the sequence read archive of NCBI (http: / / www.ncbi.nlm.nih.gov / bioproject/669334, accessed on 7 July 2021).

Acknowledgments: We are grateful to Turhan Markussen for his useful comments on the RNA-Seq experimental design. We are also grateful to Erik Rasmussen for his technical assistance with the RNA quality assessment using the Agilent's Bioanalyzer.

Conflicts of Interest: The authors have stated explicitly that there are no conflict of interest in connection with this article.

\section{References}

1. Gerba, C.P. Environmentally transmitted pathogens. Environ. Microbiol. 2015, 509-550. [CrossRef]

2. Craighead, S.; Huang, R.; Chen, H.; Kniel, K.E. The Use of Pulsed Light to Inactivate Cryptosporidium parvum Oocysts on High-Risk Commodities (Cilantro, Mesclun Lettuce, Spinach, and Tomatoes). Food Control 2021, 126, 107965. [CrossRef] 
3. Gérard, C.; Franssen, F.; La Carbona, S.; Monteiro, S.; Cozma-Petruţ, A.; Utaaker, K.S.; Režek Jambrak, A.; Rowan, N.; RodríguezLazaro, D.; Nasser, A.; et al. Inactivation of parasite transmission stages: Efficacy of treatments on foods of non-animal origin. Trends Food Sci. Technol. 2019, 91, 12-23. [CrossRef]

4. Gibson, K.E.; Almeida, G.; Jones, S.L.; Wright, K.; Lee, J.A. Inactivation of bacteria on fresh produce by batch wash ozone sanitation. Food Control 2019, 106, 106747. [CrossRef]

5. Pan, H.A.O.; Buenconsejo, M.; Reineke, K.F.; Shieh, Y.C. Effect of process temperature on virus inactivation during high hydrostatic pressure processing of contaminated fruit puree and juice. J. Food Prot. 2016, 79, 1517-1526. [CrossRef] [PubMed]

6. Fayer, R.; Morgan, U.; Upton, S.J. Epidemiology of Cryptosporidium: Transmission, detection and identification. Int. J. Parasitol. 2000, 30, 1305-1322. [CrossRef]

7. Bouzid, M.; Hunter, P.R.; Chalmers, R.M.; Tyler, K.M. Cryptosporidium pathogenicity and virulence. Clin. Microbiol. Rev. 2013, 26, 115-134. [CrossRef]

8. Gharpure, R.; Perez, A.; Miller, A.D.; Wikswo, M.E.; Silver, R.; Hlavsa, M.C. Cryptosporidiosis Outbreaks-United States, 2009-2017. Morb. Mortal. Wkly. Rep. 2019, 68, 568-572. [CrossRef]

9. $\quad$ Ethelberg, S.; Lisby, M.; Vestergaard, L.S.; Enemark, H.L.; Olsen, K.E.P.; Stensvold, C.R.; Nielsen, H.V.; Porsbo, L.J.; Plesner, A.M.; MØLbak, K. A foodborne outbreak of Cryptosporidium hominis infection. Epidemiol. Infect. 2009, 137, 348-356. [CrossRef]

10. Pönka, A.; Kotilainen, H.; Rimhanen-Finne, R.; Hokkanen, P.; Hänninen, M.L.; Kaarna, A.; Meri, T.; Kuusi, M. A foodborne outbreak due to Cryptosporidium parvum in Helsinki, November 2008. Eurosurveillance 2009, 14, 19269. [CrossRef]

11. Rousseau, A.; Carbona, S.L.; Dumètre, A.; Robertson, L.J.; Gargala, G.; Escotte-Binet, S.; Favennec, L.; Villena, I.; Gérard, C.; Aubert, D. Methods to assess viability and infectivity of Giardia duodenalis cysts, and Cryptosporidium spp., and Toxoplasma gondii oocysts: A review of the status. Parasite 2018, 25. [CrossRef] [PubMed]

12. Murphy, J.L.; Arrowood, M.J. Cell Culture Infectivity to Assess Chlorine Disinfection of Cryptosporidium Oocysts in Water. In Cryptosporidium: Methods and Protocols; Mead, J.R., Arrowood, M.J., Eds.; Springer: New York, NY, USA, 2020; pp. $283-302$. [CrossRef]

13. Murphy, J.L.; Arrowood, M.J.; Lu, X.; Hlavsa, M.C.; Beach, M.J.; Hill, V.R. Effect of cyanuric acid on the inactivation of Cryptosporidium parvum under hyperchlorination conditions. Environ. Sci. Technol. 2015, 49, 7348-7355. [CrossRef]

14. Shin, G.A.; Linden, K.G.; Arrowood, M.J.; Sobsey, M.D. Low-pressure UV inactivation and DNA repair potential of Cryptosporidium parvum oocysts. Appl. Environ. Microbiol. 2001, 67, 3029-3032. [CrossRef] [PubMed]

15. Zimmer, J.L.; Slawson, R.M.; Huck, P.M. Inactivation and potential repair of Cryptosporidium parvum following low- and mediumpressure ultraviolet irradiation. Water Res. 2003, 37, 3517-3523. [CrossRef]

16. Morita, S.; Namikoshi, A.; Hirata, T.; Oguma, K.; Katayama, H.; Ohgaki, S.; Motoyama, N.; Fujiwara, M. Efficacy of UV irradiation in inactivating Cryptosporidium parvum oocysts. Appl. Environ. Microbiol. 2002, 68, 5387-5393. [CrossRef]

17. Yanta, C.A.; Bessonov, K.; Robinson, G.; Troell, K.; Guy, R.A. CryptoGenotyper: A new bioinformatics tool for rapid Cryptosporidium identification. Food Waterborne Parasitol. 2021, 23, e00115. [CrossRef]

18. UKWIR. Cryptosporidium: Enhancing the Water Industry's Capability to Respond; Report Ref. No. 20/DW/06/22; UKWIR Limited: Westminster, UK; London, UK, 2020.

19. Fayer, R.; Nerad, T. Effects of low temperatures on viability of Cryptosporidium parvum oocysts. Appl. Environ. Microbiol. 1996, 62, 1431-1433. [CrossRef]

20. Travaillé, E.; La Carbona, S.; Gargala, G.; Aubert, D.; Guyot, K.; Dumètre, A.; Villena, I.; Houssin, M. Development of a qRT-PCR method to assess the viability of Giardia intestinalis cysts, Cryptosporidium spp. and Toxoplasma gondii oocysts. Food Control 2016, 59, 359-365. [CrossRef]

21. Dobin, A.; Davis, C.A.; Schlesinger, F.; Drenkow, J.; Zaleski, C.; Jha, S.; Batut, P.; Chaisson, M.; Gingeras, T.R. STAR: Ultrafast universal RNA-seq aligner. Bioinformatics 2013, 29, 15-21. [CrossRef]

22. Patro, R.; Duggal, G.; Love, M.I.; Irizarry, R.A.; Kingsford, C. Salmon provides fast and bias-aware quantification of transcript expression. Nat. Methods 2017, 14, 417-419. [CrossRef]

23. Liao, Y.; Smyth, G.K.; Shi, W. featureCounts: An efficient general purpose program for assigning sequence reads to genomic features. Bioinformatics 2013, 30, 923-930. [CrossRef]

24. Love, M.I.; Huber, W.; Anders, S. Moderated estimation of fold change and dispersion for RNA-seq data with DESeq2. Genome Biol. 2014, 15, 550. [CrossRef] [PubMed]

25. Aziz, N.; Jamil, R. Biochemistry, Xanthine Oxidase. Available online: https://www.ncbi.nlm.nih.gov/books/NBK545245/ (accessed on 12 March 2021).

26. Lippuner, C.; Ramakrishnan, C.; Basso, W.U.; Schmid, M.W.; Okoniewski, M.; Smith, N.C.; Hässig, M.; Deplazes, P.; Hehl, A.B. RNA-Seq analysis during the life cycle of Cryptosporidium parvum reveals significant differential gene expression between proliferating stages in the intestine and infectious sporozoites. Int. J. Parasitol. 2018, 48, 413-422. [CrossRef] [PubMed]

27. Matos, L.V.S.; McEvoy, J.; Tzipori, S.; Bresciani, K.D.S.; Widmer, G. The transcriptome of Cryptosporidium oocysts and intracellular stages. Sci. Rep. 2019, 9, 7856. [CrossRef] [PubMed]

28. Tandel, J.; English, E.D.; Sateriale, A.; Gullicksrud, J.A.; Beiting, D.P.; Sullivan, M.C.; Pinkston, B.; Striepen, B. Life cycle progression and sexual development of the apicomplexan parasite Cryptosporidium parvum. Nat. Microbiol. 2019, 4, $2226-2236$. [CrossRef] 
29. Templeton, T.J.; Lancto, C.A.; Vigdorovich, V.; Liu, C.; London, N.R.; Hadsall, K.Z.; Abrahamsen, M.S. The Cryptosporidium oocyst wall protein is a member of a multigene family and has a homolog in Toxoplasma. Infect. Immun. 2004, 72, 980-987. [CrossRef] [PubMed]

30. Nishinaka, Y.; Masutani, H.; Nakamura, H.; Yodoi, J. Regulatory roles of thioredoxin in oxidative stress-induced cellular responses. Redox Rep. 2001, 6, 289-295. [CrossRef]

31. Bajszár, G.; Dekonenko, A. Stress-induced Hsp70 Gene expression and inactivation of Cryptosporidium parvum oocysts by chlorine-based oxidants. Appl. Environ. Microbiol. 2010, 76, 1732. [CrossRef]

32. Garcés-Sanchez, G.; Wilderer, P.A.; Horn, H.; Munch, J.-C.; Lebuhn, M. Assessment of the viability of Cryptosporidium parvum oocysts with the induction ratio of hsp70 mRNA production in manure. J. Microbiol. Methods 2013, 94, 280-289. [CrossRef]

33. Lee, S.-U.; Joung, M.; Ahn, M.-H.; Huh, S.; Song, H.; Park, W.-Y.; Yu, J.-R. CP2 gene as a useful viability marker for Cryptosporidium parvum. Parasitol. Res. 2008, 102, 381-387. [CrossRef]

34. Chambers, C.D. Development and application of a molecular viability assay for Cryptosporidium parvum based on heat shock protein 70 gene expression: A thesis presented in partial fulfilment of the requirements for the degree of Master of Science in Microbiology at Massey University. Ph.D. Thesis, Massey University, Auckland, New Zealand, 2005.

35. Widmer, G.; Orbacz, E.A.; Tzipori, S. Beta-tubulin mRNA as a marker of Cryptosporidium parvum oocyst viability. Appl. Environ. Microbiol. 1999, 65, 1584-1588. [CrossRef] [PubMed]

36. Chauret, C.P.; Radziminski, C.Z.; Lepuil, M.; Creason, R.; Andrews, R.C. Chlorine dioxide inactivation of Cryptosporidium parvum oocysts and bacterial spore indicators. Appl. Environ. Microbiol. 2001, 67, 2993-3001. [CrossRef] [PubMed]

37. Korich, D.G.; Mead, J.R.; Madore, M.S.; Sinclair, N.A.; Sterling, C.R. Effects of ozone, chlorine dioxide, chlorine, and monochloramine on Cryptosporidium parvum oocyst viability. Appl. Environ. Microbiol. 1990, 56, 1423-1428. [CrossRef] [PubMed] 